\title{
Study on Association of APOB Gene Polymorphism with Glycation of Low Density Lipoproteinin Type 2 Diabetes
}

\author{
Kapil Dev1, Seema Garg ${ }^{1}$, Suman B Sharma ${ }^{1 *}$, Amitesh Aggarwal' and Madhu SV ${ }^{2}$
}

${ }^{1}$ Department of Biochemistry, University College of Medical Sciences (University of Delhi) and G.T.B. Hospital, Dilshad Garden, Delhi-110095, India ${ }^{2}$ Department of Medicine, University College of Medical Sciences (University of Delhi) and G.T.B. Hospital, Dilshad Garden, Delhi-110095, India

\begin{abstract}
Objectives: Sustained hyperglycemia results in non-enzymatic glycation of Apo B or LDL particle which may affect its recognition and uptake. Increase in circulating LDL levels is a vital contributor for atherosclerosis. APOB gene (c.12669 G>A, p.GLN4154LYS) polymorphism is believed to be associated with coronary artery disease. We thus designed our study to evaluate association of APOB gene polymorphism with Apo B glycation in type 2 diabetic patients.

Methods: A total of 45 non diabetic controls and 45 type 2 diabetic patients participated in this study. Following an overnight fast, venous blood was collected and analyzed for glycemic status, lipid profile and other biochemical parameters. Apo B was estimated using nephelometry, Glycated LDL was estimated by ELISA. PCR-RFLP was used to determine the DNA polymorphism in the APOB gene using EcoR1.

Results: Polymorphic analysis of APOB gene in diabetic population showed $73.3 \%$ wild type $(\mathrm{R}+/ \mathrm{R}+), 20.0 \%$ heterozygous mutant (R+/R-) and $6.7 \%$ homozygous mutant (R-/R-). Significant associations of glycated LDL was observed with R-/R- and R+/R- when compared with R+/R+. Significant association was not observed between Apo $B$ levels and of genotypes.

Conclusions: Presence of polymorphism may not affect the expression Apo B level but acts as an important contributor to LDL modification and increases its glycation. Since glycation of LDL reduces uptake of LDL by LDL receptors, it may increase the risk of atherosclerosis.
\end{abstract}

Keywords: Apo B; Glycated LDL; Percent glycated apoB; Diabetes mellitus; Gene polymorphism; Lipid profile

Abbreviations: Apo B: Apolipoprotein B; Ages: Advanced Glycated End Products; T2DM: Type 2 Diabetes Mellitus; CAD: Coronary Artery Disease; ADA: American Diabetic Association; BMI: Body Mass Index; ELISA: Enzyme Linked Immunosorbent Assay; GOD-POD: Glucose Oxidase- Peroxidase; Hb: Hemoglobin; HPLC: High Performance Liquid Chromatography; HDL-C: High Density Lipoprotein Cholesterol; LDL-C: Low Density Lipoprotein Cholesterol; PCR: Polymerase Chain Reaction; SNP: Single Nucleotide Polymorphism; WC: Waist Circumference

\section{Introduction}

Chronic hyperglycemia is an important etiologic factor resulting in macro and microvascular complications in diabetes mellitus (DM). The most common and life threatening disorder in type 2 diabetics is cardiovascular disease (CVD). The risk for death by CVD among diabetic subjects is greater by three folds when compared to nondiabetic subjects [1]. The risk of CVD is markedly increased in patients with poor glycemic control [2]. Increased extracellular glucose leads to non enzymatic glycation of various proteins resulting from interaction of glucose with free amino groups of lysine residue of protein. Sustained hyperglycemia, through advanced glycated end products (AGEs) is potential contributor for glycation of low density lipoprotein (LDL) [3]. The modification by AGEs can occur at Apo B as well as phospholipids components of LDL [3]. Increased non-enzymatic glycation of Apo B containing lipoproteins is one of the post-secretory modifications which impair its uptake and metabolism by the high affinity low density lipoprotein (LDL) receptors. This increases the residence time for the modified LDL in circulation and subendothelium, which is taken up by macrophages resulting in formation of foam cells and thus may contribute to increased risk of atherosclerosis [3].
Apolipoprotein B (Apo B) plays a central role in human lipoprotein metabolism and is encoded by APOB gene located on chromosome 2 [4]. Apo B-100 is ligand for LDL-receptor-mediated endocytosis of LDL particles. Raised serum ApoB levels are associated with increased risk of coronary artery disease (CAD) $[5,6]$ and several APOB polymorphisms have been evaluated for their association with lipid levels and CAD in different populations [7-10]. One such polymorphism in the 29th exon (c.12669 G>A) results in Glu4154Lys amino acid substitution. This polymorphism can be detected by using EcoRI restriction enzyme. Gene polymorphism may have its consequences ranging from effect on structure function relationship of a protein or alteration in protein expression level. Role of the APOB gene polymorphism in coronary artery disease in the Indian Punjabi population has been evaluated by Sharma et al. [8]. Thus we designed this study to evaluate the effect of APOB gene polymorphism on levels of Apo B containing lipoproteins and their glycation.

\section{Methods}

The present cross sectional case control study was carried out in

*Corresponding author: Dr. S B Sharma, Professor, Department of Biochemistry, University College of Medical Sciences (University of Delhi) and G.T.B. Hospital Dilshad Garden, Delhi-110095, India, Tel: +91 9818041119; Fax: 91-11-22950495; E-mail:drsbs08@hotmail.com

Received April 15, 2015; Accepted May 14, 2015; Published May 20, 2015

Citation: Dev K, Garg S, Sharma SB, Aggarwal A, Madhu SV (2015) Study on Association of APOB Gene Polymorphism with Glycation of Low Density Lipoproteinin Type 2 Diabetes. J Diabetes Metab 6: 553. doi:10.4172/2155 6156.1000553

Copyright: (c) 2015 Dev K, et al. This is an open-access article distributed under the terms of the Creative Commons Attribution License, which permits unrestricted use, distribution, and reproduction in any medium, provided the original author and source are credited. 
the Department of Biochemistry and Medicine, at University College of Medical Sciences and Guru Teg Bahadur Hospital, Delhi-110095, between Nov 2012 and Apr 2013. Ethical clearance was obtained from the institutional ethical committee for human studies (UCMS/IEC$\mathrm{HR} / \mathrm{BIO} / 261012$ dated 26 Oct, 2012). All the patients were recruited from the Diabetic clinic and Medicine outpatient department (OPD) of GTB Hospital

\section{Recruitment of patients and control}

We recruited 45 diabetic patients in the age group of 40-60 years irrespective of the gender, as per to new guidelines of American Diabetes Association (ADA) 2013 [11].

All patients on lipid lowering therapy, Insulin therapy and pioglitazone therapy were excluded from the study. Patients on corticosteroids, retinoid drugs, immune suppressive drugs, betablockers, and steroid hormones were also excluded from the study. Forty five apparently healthy non diabetic non hypertensive controls in age groups of 40-60years were also recruited.

An informed written consent was obtained from each participant before recruitment, and each participant was provided with a patient information sheet. A detailed history was recorded and clinical examination including general physical examination was carried out before collecting blood samples.

\section{Blood collection and biochemical analysis}

For all subjects, blood samples were collected after an overnight fasting. Blood collected in plain vials were allowed to clot for 30 minutes and then it was centrifuged at 3000rpm for $10 \mathrm{~min}$ for serum separation. The serum thus separated was analyzed for routine biochemical parameters using Olympus AU400, Japan. Serum cholesterol [12], HDL cholesterol [13], and triglycerides [14] were analysed using commercially available kits on the autoanalyzer. Blood in fluoride vial for plasma glucose (fasting and 2 hour post prandial) was analysed using standard enzymatic method (GOD-POD method) [15]. LDL cholesterol was calculated using Freidwald formula [16]. Serum Apo B was estimated by nephelometry, using NEPHSTAR apolipoprotein $B$ kit. Whole blood with EDTA was used for HbAlc estimation by HPLC method (BIO RAD, D-10). EDTA blood was subjected to centrifugation at $3000 \mathrm{rpm}$ for 10 minutes to separate the plasma. The plasma thus separated was stored in aliquots at $-80^{\circ} \mathrm{C}$ for estimation of glycated Apo B using commercially available kit (Glycacor TM by Exocell Philadelphia, USA) based on competitive ELISA. The glycated LDL was measured in apolipoprotein B equivalents, and was expressed as mg/dl. Percent glycated Apo B was calculated as Glycated Apo B/ Apo B

For genomic study $300 \mu \mathrm{l}$ whole blood in EDTA was kept separately at $4-8^{\circ} \mathrm{C}$. This blood was subjected to DNA isolation within 2 weeks of collection.

\section{Polymorphic study for APOB gene}

Genomic DNA was extracted from whole blood by commercially available kit (SIGMA DNA isolation $\mathrm{kit}^{\mathrm{TM}}$ ) as per the instructions provided by the manufacturer. PCR reactions were carried out in 20 $\mu \mathrm{l}$ reaction mixture using the forward and reverse primers for the $376 \mathrm{bp}$ sequence with restriction site for EcoR1 in Apo B gene. 20 $\mu \mathrm{l}$ reaction mixture was prepared containing $2.5 \mu \mathrm{l}$ genomic DNA, $200 \mu \mathrm{M}$ dNTPs, $1.5 \mathrm{mM} \mathrm{MgCl}$, Taq reaction buffers and $2 \mathrm{U}$ Taq DNA Polymerase. The primer sequences were: forward primer $(\mathrm{F})$ 5'--GCTCACCCTGAGAGAAGTGTCTFCA-3' and reverse primers
(R) 5'--CATAGTGCAAAGTTCCTCCCTAGTG-3'. After initial melting temperature of $94^{\circ} \mathrm{C}(5 \mathrm{~min}), 30$ cycles of denaturation, annealing, and extension $\left(2 \mathrm{~min}\right.$ at $94^{\circ} \mathrm{C}, 1 \mathrm{~min} 59^{\circ} \mathrm{C}$ and extension for $1 \mathrm{~min}$ at $72^{\circ} \mathrm{C}$ ) were carried out on a programmed thermocycler ( Eppendorf Mastercycler Gradient-5331). A final 10 min extension step at $72^{\circ} \mathrm{C}$ terminated the process.

The PCR-products were then digested in $45 \mu \mathrm{l}$ reaction mixture using $4 \mathrm{U}$ of EcoR1, BSA, (Genei Merck) and $12.5 \mu \mathrm{l}$ of PCR mix. After activation step at $37^{\circ} \mathrm{C}$ for 45 minutes was followed by inactivation step at $65^{\circ} \mathrm{C}$ for 10 minutes. The products were run on $2.5 \%$ agarose gel in $1 \mathrm{X}$ Tris-acetate ethylenediamintetraacetic (TAE) buffer and ethidium bromide dye at a constant voltage of $50 \mathrm{~V}$ and the gel was visualised on the gel documentation system (UVITEC). Three types of bands were visualized. The cutting site for EcoRI was based on a single base-pair mutation atgene (c.12669 G>A). An uncut fragment with a size of 376 $\mathrm{bp}$ was defined as the $\mathrm{R}$ - allele; when digested, the two resulting sub fragments of 260 and $116 \mathrm{bp}$ were defined as the R+ allele (Figure 1).

\section{Statistical analysis}

Data was analysed using SPSS software version 20.0. The data in the two groups were analysed using students' $t$ ' test. The allele frequency was calculated using gene counting method. Comparison of the categorical data i.e., different APOB genotypes among controls and obese subjects was done by Fischer's exact test and $\chi 2$ test. Odd's ratios were calculated with a $95 \%$ confidence interval limit using $2 \times 2$ contingency table. Two way ANOVA was applied for all parameters taking group as $1^{\text {st }}$ factor and polymorphism as $2^{\text {nd }}$ factor. If interaction between groups and polymorphism was $<0.15$, we applied one way ANOVA to compare within group and Tukey's test for multiple comparisons. To compare between groups, $\mathrm{t}$ test was applied and $\mathrm{p}$-value was adjusted as Bonn Ferroni correction i.e. $0.05 / 3 \approx 0.02$.

\section{Results}

The mean age in control group was $47 \pm 7.18$ years and in diabetic group $48.8 \pm 5.84$ years. In diabetic group, there were $26(57.8 \%)$ males and $19(42.2 \%)$ females, where as in control group, 29 (64.4\%) males and $16(35.5 \%)$ females were present. Hypertensive patients were identified according to the seventh report of the Joint National Committee on prevention, detection, evaluation and treatment of high blood pressure (JNC VII) [17]. 23 individuals (51\%) in diabetic group were found to be hypertensive. Using waist circumference as the criteria for diagnosis of obesity [18], it was observed that $33(73.4 \%)$ in diabetic group and $30(66.6 \%)$ subjects in control group were obese. There were $4(8.8 \%)$ smokers in diabetic group and $3(6.6 \%)$ smokers in control group. Other clinical and anthropometric variables are compared in Table 1 . Statistically significant difference was not
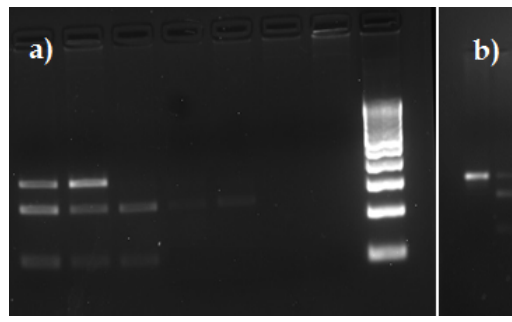

Figure 1: Agarose Gel Electrophoresis of Eco R1digested APOB gene after PCR amplification: (a) shows DNA marker in 11, R-/R- in 1 and 8 , and R+/R- in 2,3,4,7,9,10; (b) shows DNA marker in 8, R+/R- in 1 and 2, R+/R+ in 3, 4 and 5. 
Citation: Dev K, Garg S, Sharma SB, Aggarwal A, Madhu SV (2015) Study on Association of APOB Gene Polymorphism with Glycation of Low Density Lipoproteinin Type 2 Diabetes. J Diabetes Metab 6: 553. doi:10.4172/2155-6156.1000553

Page 3 of 4

observed in lipid profile between the two study groups (Table 1). Table 2 shows comparison of Apo B levels and glycated LDL between two groups. The frequency of $\mathrm{R}+$ and $\mathrm{R}$ - alleles was calculated (with an allele counting method) in diabetic and non-diabetic group. Genotype variants and allele frequency in the two groups is given in Table 3. No deviation was observed on applying Hardy Weinberg Equilibrium test in the control group ( $\mathrm{p}=0.196)$ as well as in diabetes group ( $\mathrm{p}=0.067)$. Odds ratio revealed no significant association between genotypes with diabetes. On applying two way ANOVA, interaction was found to be significant only for Apo B, glycated LDL and percent glycated Apo B $(<0.15)$. A significant difference was observed for glycated LDL and percent glycated apo B amongst genotypes in diabetic groups as shown in Table 4 . While carrying out intergroup comparison for each genotype, it was observed that glycated LDL was higher in diabetic group in each genotype although difference was statistically significant only for $\mathrm{R}+\mathrm{R}+(\mathrm{p}=0.000)$. Similar pattern was observed for percent glycated apo $B$ in which significantly higher values were observed for $\mathrm{R}+\mathrm{R}+(\mathrm{p}=0.010)$ in diabetic group. However significant difference was not observed in Apo B concentration for each genotype while carrying out within group and between groups comparison.

\section{Discussion}

Patients with diabetes frequently suffer from dyslipidemia which is characterized in part by defective lipoprotein uptake and metabolism [19-21]. Since earlier studies have indicated that APOB polymorphism is associated with $\mathrm{CAD}$, we designed our study to analyse the effect of APOB polymorphism on lipid profile and extent of glycation of LDL. $\mathrm{R}^{+}$allele was found to be more common in our population. Similar results were reported from Punjab and Tamil Nadu also $[8,22]$. There was no statistically significant difference in the LDL-C or any other lipid parameters among different genotypes of APOB in our study population. This is in line with other studies on different ethnic populations in India $[8,22]$. Both studies observed no association between total or LDL cholesterol levels with different APOB genotypes in CAD patients as well as normal subjects $[8,22]$. In addition, Delghandi et al studied DNA polymorphisms of the APOB gene (XbaI, EcoRI, and MspI RFLPs) in Norwegians population and concluded that variations in the EcoR1 APOB gene polymorphism, does not affect the circulating blood lipids [7]. Contrary to all these studies, Timirci et al. observed that polymorphism of this gene affects total cholesterol and LDLcholesterol levels in obese children in Turkish population [23]. These

\begin{tabular}{|c|c|c|c|}
\hline Variables & $\begin{array}{l}\text { Control group } \\
(n=45)\end{array}$ & $\begin{array}{l}\text { Diabetic group } \\
(n=45)\end{array}$ & p value \\
\hline Height (cms) & $162.28 \pm 7.75$ & $154.42 \pm 8.24$ & .000 \\
\hline Weight(kg) & $70 \pm 11.37$ & $63.06 \pm 10.12$ & 0.003 \\
\hline Body Mass Index (kg/m2) & $26.56 \pm 4.29$ & $25.63 \pm 3.78$ & 0.278 \\
\hline Waist circumference(cms) & $90.12 \pm 15.38$ & $88.95 \pm 14.83$ & 0.323 \\
\hline Hip circumference (cms) & $90.4 \pm 17.00$ & $89 \pm 14.02$ & 0.104 \\
\hline Waist Hip Ratio & $0.98 \pm 0.056$ & $1.00 \pm 0.057$ & 0.134 \\
\hline $\begin{array}{l}\text { Fasting plasma glucose }(\mathrm{mg} / \\
\text { dl) }\end{array}$ & $89.73 \pm 10.49$ & $131.15 \pm 40.41$ & 0.000 \\
\hline $\begin{array}{l}\text { Post prandial plasma } \\
\text { glucose(mg/dl) }\end{array}$ & $128.77 \pm 16.30$ & $199.97 \pm 56.72$ & 0.000 \\
\hline Hb1Ac (\%) & $5.38 \pm 0.39$ & $7.56 \pm 1.99$ & 0.000 \\
\hline Total cholesterol (mg/dl) & $187.08 \pm 24.014$ & $197.24 \pm 39.50$ & 0.145 \\
\hline HDL- cholesterol (mg/dl) & $45 \pm 8.68$ & $43.37 \pm 7.45$ & 0.344 \\
\hline LDL- cholesterol (mg/dl) & $118.96 \pm 19.76$ & $128.25 \pm 34.24$ & 0.119 \\
\hline Triglycerides (mg/dl) & $115.62 \pm 39.60$ & $128.044 \pm 49.23$ & 0.191 \\
\hline
\end{tabular}

Values are expressed as mean $\pm S D, p<0.05$ is significant

Table 1: Clinical and biochemical profile among study groups.

\begin{tabular}{|c|c|c|c|}
\hline Variables & $\begin{array}{c}\text { Control group } \\
\qquad(n=45)\end{array}$ & $\begin{array}{c}\text { Diabetic group } \\
(n=45)\end{array}$ & $p$ value \\
\hline Apo B (g/L) & $1.08 \pm 0.37$ & $1.20 \pm 0.42$ & 0.887 \\
\hline Glycated LDL (mg/dl) & $0.95 \pm 0.05$ & $1.83 \pm 1.00$ & 0.000 \\
\hline Percent glycated apo B & $0.90 \pm 0.00$ & $1.68 \pm 1.12$ & 0.000 \\
\hline
\end{tabular}

Table 2: Comparison of Apo B and glycated LDL among study groups.

\begin{tabular}{|c|c|c|c|c|c|c|}
\hline $\begin{array}{c}\text { Polymorphic } \\
\text { variants }\end{array}$ & $\begin{array}{c}\text { Control } \\
\text { group(n=45) }\end{array}$ & $\begin{array}{c}\text { Diabetic } \\
\text { group(n=45) }\end{array}$ & $\begin{array}{c}\text { Odds } \\
\text { ratio }\end{array}$ & 95\% Cl & \multicolumn{2}{|c|}{$\begin{array}{c}\text { p value } \\
\text { chi sq }\end{array}$} \\
\hline R+/R+ & $28(62.2 \%)$ & $33(73.3 \%)$ & 1.0 & & 0.259 & \\
\cline { 1 - 5 } R+/R- & $13(28.9 \%)$ & $9(20.0 \%)$ & 0.913 & $0.328-2.55$ & 0.527 & 0.982 \\
\hline R-/R- & $4(8.9 \%)$ & $3(6.7 \%)$ & 0.913 & $0.185-4.50$ & 1.00 & \multirow{2}{*}{0.502} \\
\hline R+ Allele & 69 & 75 & 0.776 & $0.371-1.625$ & & 0.502 \\
\hline R- Allele & 21 & 15 & 1 & & & \\
\hline
\end{tabular}

Table 3: Polymorphic variants and allele frequency in study groups.

\begin{tabular}{|c|c|c|c|}
\hline Parameters & Genotypes & Control group & Diabetic group \\
\hline \multirow{3}{*}{ Total cholesterol (mg/dl) } & $\mathrm{R}^{+} / \mathrm{R}^{+}$ & $180.18 \pm 25.39$ & $200.33 \pm 38.79$ \\
\hline & $\mathrm{R}^{+} / \mathrm{R}^{-}$ & $199.79 \pm 17.17$ & $179.25 \pm 27.44$ \\
\hline & $\mathrm{R} / \mathrm{R}^{-}$ & $188.50 \pm 19.09$ & $214.00 \pm 79.64$ \\
\hline \multirow{3}{*}{ HDL - Cholesterol(mg/dl) } & $\mathrm{R}^{+} / \mathrm{R}^{+}$ & $43.93 \pm 9.10$ & $43.33 \pm 7.65$ \\
\hline & $\mathrm{R}^{+} / \mathrm{R}^{-}$ & $49.57 \pm 10.95$ & $43.38 \pm 7.84$ \\
\hline & $R^{-} / R^{-}$ & $55.00 \pm 7.70$ & $44.67 \pm 8.08$ \\
\hline \multirow{3}{*}{ LDL- Cholesterol(mg/dl) } & $\mathrm{R}^{+} / \mathrm{R}^{+}$ & $114.96 \pm 20.63$ & $129.46 \pm 33.58$ \\
\hline & $\mathrm{R}^{+} / \mathrm{R}^{-}$ & $122.41 \pm 17.43$ & $113.45 \pm 22.05$ \\
\hline & $\mathrm{R}-/ \mathrm{R}^{-}$ & $118.35 \pm 9.24$ & $143.73 \pm 65.36$ \\
\hline \multirow{3}{*}{ Triglycerides (mg/dl) } & $\mathrm{R}^{+} / \mathrm{R}^{+}$ & $106.64 \pm 38.55$ & $137.73 \pm 50.9$ \\
\hline & $\mathrm{R}^{+} / \mathrm{R}^{-}$ & $109.71 \pm 31.63$ & $97.13 \pm 26.54$ \\
\hline & $\mathrm{R}^{-} / \mathrm{R}^{-}$ & $117.00 \pm 44.74$ & $128.0 \pm 38.12$ \\
\hline \multirow{3}{*}{ Apo B(g/L) } & $\mathrm{R}^{+} / \mathrm{R}^{+}$ & $1.11 \pm 037$ & $1.24 \pm 0.44$ \\
\hline & $\mathrm{R}^{+} / \mathrm{R}^{-}$ & $1.23 \pm 0.41$ & $1.09 \pm 0.39$ \\
\hline & $\mathrm{R}^{-} / \mathrm{R}^{-}$ & $1.06 \pm 0.17$ & $1.10 \pm 0.44$ \\
\hline \multirow{3}{*}{ Glycated LDL(g/L) } & $\mathrm{R}^{+} / \mathrm{R}^{+}$ & $0.96 \pm 0.62$ & $1.51 \pm 1.04$ \\
\hline & $\mathrm{R}^{+} / \mathrm{R}^{-}$ & $0.86 \pm 0.51$ & $1.84 \pm 0.97$ \\
\hline & $\mathrm{R}^{-} / \mathrm{R}^{-}$ & $0.79 \pm 0.47$ & $3.46 \pm 0.08^{*}$ \\
\hline \multirow{3}{*}{ Percent Glycated apo B } & $\mathrm{R}^{+} / \mathrm{R}^{+}$ & $0.99 \pm 0.64$ & $1.58 \pm 0.93$ \\
\hline & $\mathrm{R}^{+} / \mathrm{R}^{-}$ & $0.83 \pm 0.61$ & $1.62 \pm 1.16$ \\
\hline & $R^{-} / R^{-}$ & $0.73 \pm 0.39$ & $3.94 \pm 2.19^{a, b}$ \\
\hline
\end{tabular}

Table 4: Lipid profile among different genotypes in control and diabetic group.

results indicate that $\mathrm{G}>\mathrm{A}$ polymorphism has no effect on circulating lipids in most populations. However, association of genotypic variation with circulating lipids may vary in different ethnic populations.

The results of our study also reveal that glycation of LDL and ApoB is higher in diabetes and similar results have been reported earlier also [24-26]. On comparing the association of glycated LDL and percent glycation of Apo B with different genotypes, significantly higher glycation of $\mathrm{LDL}$ and $\mathrm{ApoB}$ was observed in individuals with $\mathrm{R}^{-}$allele, being highest in individuals with homozygous $\mathrm{R}$ genotypes. This finding indicates that presence of SNP $(\mathrm{G}>\mathrm{A})$ i.e. substitution of $\mathrm{Glu} \rightarrow$ Lys at codon 4154 in exon 29 of Apo B increases susceptibility of Apo B to undergo glycation and thus acts as an important contributor to LDL modification. Increased non-enzymatic glycation of Apo B containing lipoproteins impairs uptake and metabolism by the high affinity low density lipoprotein (LDL) receptor, and is one of the post-secretory modifications contributing to accelerated atherosclerosis in diabetes [27]. Glycated LDL is more susceptible to oxidative modification than 
Citation: Dev K, Garg S, Sharma SB, Aggarwal A, Madhu SV (2015) Study on Association of APOB Gene Polymorphism with Glycation of Low Density Lipoproteinin Type 2 Diabetes. J Diabetes Metab 6: 553. doi:10.4172/2155-6156.1000553

non-glycated LDL. Therefore, glycated-LDL accumulates in plasma and may enhance cholesterol ester accumulation in macrophages and thus may increase the risk of atherogenic complications [3,27]. In addition the modified LDL also stimulates vascular smooth muscle cells to produce pro oxidant and pro inflammatory state and thus contributes to atherosclerosis in diabetes [27].

Since LDL and Apo B levels are similar in all genotypes, we suggest that presence of polymorphism may not affect the expression of Apo B level but increases its susceptibility to glycation and thus may increase the risk of cardiovascular complications. The limitation of this study is relatively small sample size. So potential for selection bias may raise some concerns on the statistical precisions of the estimates.

\section{Conclusions}

The present study indicates that, $\mathrm{R}+/ \mathrm{R}+$ is the most common genotype and $\mathrm{R}-/ \mathrm{R}$ - is the least common. Though presence of SNP $(\mathrm{G}>\mathrm{A})$ may not alter phenotypes of apoB and LDL, it acts as an important contributor to LDL modification and hence may predispose the individuals to complications like atherosclerosis.

\section{Conflicts of Interest and Competing Interest Statement}

Authors declare that there is no financial or non-financial conflict of interest and competing interests.

\section{Authors' Contribution}

$\mathrm{KD}, \mathrm{SG}, \mathrm{SBS}$, and SVM designed the study, KD and SG carried out experiments and acquired data; AA, and SVM helped in recruiting patients and performed CIMT and HbA1c analysis; SG, SBS, KD, AA and SVM contributed to draft the whole project. All authors have read and approved the final manuscript.

\section{Acknowledgements}

The authors acknowledge the general technical support provided by our colleagues Dr Mohit and Dr Rajarshi.

\section{References}

1. Preis SR, Hwang SJ, Coady S, Pencina MJ, D'Agostino RB Sr, et al. (2009) Trends in all-cause and cardiovascular disease mortality among women and men with and without diabetes mellitus in the Framingham Heart Study, 1950 to 2005 . Circulation 119: 1728-1735.

2. Eckel RH, Wassef M, Chait A, Sobel B, Barrett E, et al. (2002) Prevention Conference VI: Diabetes and Cardiovascular Disease: Writing Group II: pathogenesis of atherosclerosis in diabetes. Circulation 105: e138-143.

3. Bucala R, Makita Z, Vega G, Grundy S, Koschinsky T, et al. (1994) Modification of low density lipoprotein by advanced glycation end products contributes to the dyslipidemia of diabetes and renal insufficiency. Proc Natl Acad Sci U S A 91: $9441-9445$

4. Chan L, VanTuinen P, Ledbetter DH, Daiger SP, Gotto AM Jr, et al. (1985) The human apolipoprotein B-100 gene: a highly polymorphic gene that maps to the short arm of chromosome 2. Biochem Biophys Res Commun 133: 248-255.

5. Sniderman AD, Lamarche B, Tilley J, Seccombe D, Frohlich J (2002) Hypertriglyceridemic hyperapoB in type 2 diabetes. Diabetes Care 25: 579-582.

6. Sniderman AD, Furberg CD, Keech A, Roeters van Lennep JE, Frohlich J, et al (2003) Apolipoproteins versus lipids as indices of coronary risk and as targets for statin treatment. Lancet 361: 777-780.

7. Delghandi M, Thangarajah R, Nilsen M, Grimsgaard S, Bønaa KH, et al. (1999) DNA polymorphisms of the apolipoprotein B gene (Xbal, EcoRI, and Msp RFLPs) in Norwegians at risk of atherosclerosis and healthy controls. Acta Cardiol 54: 215-225.
8. Sharma R, Mahajan M, Singh B, Singh G, Singh P (2011) Role of the APOB Gene Polymorphism (c.12669G>A, p. Gln4154Lys) in Coronary Artery Disease in the Indian Punjabi Population. Balkan J Med Genet 14: 35-40.

9. Puri RD, Tewari S, Sinha N, Ramesh V, Khan F, et al. (2003) Polymorphisms in the apolipoprotein B-100 gene: association with plasma lipid concentration and coronary artery disease. Indian Heart J 55: 60-64.

10. Scartezini M, Zago MA, Chautard-Freire-Maia EA, Pazin-Filho A, Marin-Neto JA, et al. (2003) The X-X-/E+E+ genotype of the Xbal/EcoRI polymorphisms of the apolipoprotein $\mathrm{B}$ gene as a marker of coronary artery disease in a Brazilian sample. Braz J Med Biol Res 36: 369-375.

11. American Diabetes Association (2010) Diagnosis and classification of diabetes mellitus. Diabetes Care 33 Suppl 1: S62-69.

12. Allain CC, Poon LS, Chan CS, Richmond W, Fu PC (1974) Enzymatic determination of total serum cholesterol. Clin Chem 20: 470-475.

13. Burstein M, Scholnick HR, Morfin R (1970) Rapid method for the isolation of lipoproteins from human serum by precipitation with polyanions. J Lipid Res 11: $583-595$

14. Werner M, Gabrielson DG, Eastman J (1981) Ultramicro determination of serum triglycerides by bioluminescent assay. Clin Chem 27: 268-271.

15. Sacks DB (1996). Carbohydrates. In: Brutis CA, Ashwood ER editors Tietz Textbook of Clinical Chemistry ( $3^{\text {rd }}$ edtn) Philadelphia: WB Saunders and Co. $778-780$

16. Friedewald WT, Levy RI, Fredrickson DS (1972) Estimation of the concentration of low-density lipoprotein cholesterol in plasma, without use of the preparative ultracentrifuge. Clin Chem 18: 499-502.

17. Chobanian AV, Bakris GL, Black HR, Cushman WC, Green LA, et al. (2003). The seventh report of the joint national committee on prevention, detection, evaluation and treatment of high blood pressure. JAMA 289: 2560-2571.

18. Alberti KG, Eckel RH, Grundy SM, Zimmet PZ, Cleeman JI, et al (2009) Harmonizing the metabolic syndrome: a joint interim statement of the international diabetes federation task force on epidemiology and prevention National Heart, Lung, and Blood Institute; American Heart Association; World Heart Federation; International Atherosclerosis Society; and International association for the study of obesity. Circulation 120: 1640-1645.

9. Brown WV (1994) Lipoprotein disorders in diabetes mellitus. Med Clin North Am 78: 143-161.

20. Lopes-Virella MF, Sherer GK, Lees AM, Wohltmann H, Mayfield R,et al(1982) Surface binding, internalization and degradation by cultured human fibroblasts of low density lipoproteins isolated from type 1 (insulin-dependent) diabetic patients: changes with metabolic control. Diabetologia 22: 430-436.

21. Hiramatsu K, Bierman EL, Chait A (1985) Metabolism of low-density lipoprotein from patients with diabetic hypertriglyceridemia by cultured human skin fibroblasts. Diabetes $34: 8-14$.

22. Padmaja N, Kumar MR, Adithan C (2009) Association of polymorphisms in apolipoprotein A1 and apolipoprotein B genes with lipid profile in Tamilian population. Indian Heart J 61: 51-54.

23. Timirci O, Darendeliler F, Bas F, Arzu EH, Umit Z, et al. (2010) Comparison of lipid profiles in relation to APOB EcoRI polymorphism in obese children with hyperlipidemia. In Vivo 24: 65-69.

24. Tames FJ, Mackness MI, Arrol S, Laing I, Durrington PN (1992) Non-enzymatic glycation of apolipoprotein B in the sera of diabetic and non-diabetic subjects. Atherosclerosis 93: 237-244.

25. Panteghini M, Cimino A, Pagani F, Girelli A (1995) Nonenzymic glycation of apolipoprotein $B$ in patients with insulin- and noninsulin-dependent diabetes mellitus. Clin Biochem 28: 587-592.

26. Misciagna G, Logroscino G, De Michele G, Guerra V, Cisternino AM, et al. (2007) Glycated apolipoprotein B and myocardial infarction. Nutr Metab Cardiovasc Dis 17: 6-12

27. Sima AV, Botez GM, Stancu CS, Manea A, Raicu M, et al. (2010) Effect of irreversibly glycated LDL in human vascular smooth muscle cells: lipid loading, oxidative and inflammatory stress. J Cell Mol Med 14: 2790-2802. 